\title{
ANALISIS PENGARUH KEPEMILIKAN INSTITUSIONAL, KONEKSI POLITIK, UKURAN PERUSAHAAN, ROE, DAN LEVERAGE TERHADAP SINKRONISITAS HARGA SAHAM
}

\author{
Mardianto* dan Juniyanti* \\ *Program Sarjana Akuntansi, Universitas Internasional Batam \\ Email:mardianto.zhou@uib.ac.id; juniyanti.she98@yahoo.com
}

\begin{abstract}
This scientific work is written to examine the effect of the independent variable towards the synchronicity of stock prices variable. The independent variables referred to in the scientific work are political connections, institutional ownership, ROE, company size, leverage, skewness and kurtosis. Author will elaborate the results of the variables in this research.

The LQ45 company which is well known for its financial condition, growth prospects, and high transaction value has been chosen as sample used for this study. The sampling period ranged from 2014 to 2018, which is 5 (five) years. The financial statements and annual reports of the LQ45 company are downloaded through the site https://www.idx.co.id/. Whereas the company's information regarding weekly return needed for data processing of share price synchronicity is obtained through the website https://finance.yahoo.com/. The research data obtained are then processed using Eviews application version 10 and SPSS version 22.

Results indicate that the institutional ownership variable has significant negative effect on the synchronicity of stock price. While compant size and kurtosis variables has significant positive effect on the synchronicity of stock prices. Other variables, namely political connections, Return On Equity (ROE), leverage and skewness do not have a significant relationship to the variable synchrony of stock prices.
\end{abstract}

Key words: Stock price synchronicity, political connections, institutional ownership, and Return On Equity (ROE).

\section{PENDAHULUAN}

\subsection{Latar Belakang}

Saham dapat mewakili atau melambangkan kepemilikan seseorang atas suatu perusahaan yang bersifat terbuka. Membeli saham dapat berarti kita telah memiliki hak kepemilikan atas perusahaan tersebut sesuai dengan nilai beli sahamnya. Semakin besar saham yang kita beli hak kepemilikan kita terhadap perusahaan tersebut semakin besar dan sebaliknya. Nilai harga saham perusahaan dijadikan sebagai sebuah pertimbangan yang penting bagi investor sebelum melakukan investasi di pasar modal. Jika harga saham sebuah perusahaan tinggi, dapat melambangkan perusahaan tersebut memiliki nilai yang bagus di mata masyarakat atau pasar. Namun, jika harga saham perusahaan tersebut rendah, melambangkan perusahaan tersebut dinilai kurang oleh masyarakat atau para investor di pasar.

Investor akan menggunakan informasi baru dari luar dalam pengambilan keputusan ketika perusahaan menyajikan laporan keuangan yang tidak berkualitas atau tidak dapat diandalkan bagi investor. Dengan demikian, return perusahaan akan naik dan turun sesuai dengan return pasar karena investor tidak menggunakan informasi spesifik dalam laporan tahunan perusahaan dan menyebabkan tingginya sinkronisitas harga saham. Sinkronisitas harga saham dikatakan tinggi ketika return perusahaan berbeda dengan dengan return pasar karena investor menggunakan informasi spesifik perusahaan sehingga return perusahaan akan naik dan turun sesuai dengan kinerja perusahaan bukan sesuai dengan informasi dari eksternal (Fernandes \& Ferreira, 2009). 
Terdapat banyak faktor yang dapat mempengaruhi sinkronisitas harga saham. Misalnya pada penelitian Piotroski, Wong, \& Zhang (2015) menyatakan bahwa perusahaan yang berkoneksi politik mempunyai motif untuk menahan atau menguburkan penyajian informasi negatif perusahaan pada laporan keuangan guna menjaga nama baik perusahaan dan perlindungan terhadap investor. Perusahaan dengan kepemilikan institusional tinggi memiliki tingkat sinkronisitas saham yang rendah karena investor institusional menggunakan hak secara efektif untuk memastikan transparansi laporan keuangan yang disajikan (Lyimo, 2014).

Penelitian yang dilakukan oleh Wen, Yuan, \& Zhou (2019) memperoleh hasil bahwa variabel ukuran perusahaan terdapat pengaruh secara signifikan positif dengan variabel sinkronisitas harga saham. Semakin besar ukuran perusahaan maka semakin tinggi tingkat sinkronisitas harga saham. Faktor lain seperti Return On Equity (ROE) dan leverage juga memiliki hubungan yang signifikan terhadap sinkronisitas harga saham (Gul, Kim, \& Qiu, 2010).

\section{KERANGKA TEORETIS DAN PERUMUSAN HIPOTESIS}

\subsection{Sinkronisitas Harga Saham}

Sinkronisitas harga saham sebagai variabel dependen pada penelitian ini dapat didefinisikan sebagai sejauh mana pengembalian pasar menjelaskan variasi dalam tingkat pengembalian saham perusahaan (Piotroski \& Roulstone, 2016). Sinkronisitas harga saham digunakan sebagai ukuran jumlah relatif dari informasi perusahaan yang tercermin dalam pengembalian harga saham (Morck, Yeung, \& $\mathrm{Yu}$, 2000). Semakin tinggi tingkat sinkronisitas harga saham menunjukkan semakin rendahnya informasi perusahaan yang dicerminkan pada harga saham di pasar (Purwoto, 2011).

Sinkronisitas harga saham mengacu pada sejauh mana harga saham naik dan turun secara bersamaan (Du, Hao, \& Xu, 2007).
Tingkat sinkronisitasi harga saham yang tinggi mencerminkan lebih banyak kesamaan mengenai informasi luar perusahaan dengan harga saham perusahaan dibandingkan informasi internal perusahaan dengan harga saham dan sebaliknya (Kun, B, \& Hu, 2018). Fenomena bahwa harga saham perusahaan bergerak dengan indeks pasar disebut sinkronisitas harga saham (Liu, 2015).

\subsection{Model Penelitian Terdahulu}

Penelitian mengenai sinkronisitas harga saham telah banyak diteliti oleh peneliti-peneliti sebelumnya. Model penelitian terdahulu yang meneliti tentang hubungan volatilitas pasar saham dan ukuran perusahaan dengan sinkronisitas harga saham pernah dilakukan oleh Cheng, Lim, Sing, \& Wang (2017) dengan menggunakan data empiris untuk 40 negara. Penelitian ini memberikan hasil bahwa volatilitas pasar saham dan ukuran perusahaan berhubungan secara signifikan terhadap sinkronisitas harga saham.

Penelitian Liu \& Zhang (2018) berfokus pada dampak pengetahuan keuangan investor terhadap sinkronisitas harga saham. Mereka berpendapat bahwa informasi spesifik perusahaan yang tercermin ke dalam harga saham dipengaruhi oleh pengungkapan perusahaan dan interpretasi investor dari informasi yang diungkapkan. Literasi keuangan dapat meningkatkan bagaimana investor memahami laporan keuangan dan pengungkapan perusahaan yang dapat menyebabkan rendahnya sinkronisitas harga saham. Peneliti menemukan bahwa sinkronisitas harga saham yang tinggi terjadi di negara-negara dengan tingkat literasi keuangan investor yang rendah. Hasil penelitian ini menunjukkan bahwa terdapat pengaruh signifikan negatif antara literasi keuangan investor dan sinkronisitas harga saham.

Sebuah penelitian yang dilakukan Farooq, Ahmed, \& Bouaddi (2018) menyelidiki apakah sinkronisitas harga saham mengandung informasi mengenai volatilitas pasar saham. Mereka menemukan hubungan positif secara signifikan antara sinkronisitas 
harga saham dan volatilitas pasar saham selama periode antara tahun 2005 sampai dengan tahun 2010. Mereka menunjukkan bahwa saham bergerak naik menyebabkan volatilitas pasar saham naik secara bersamaan.

\subsection{Hubungan Antar Variabel}

\subsubsection{Pengaruh Koneksi Politik Terhadap Sinkronisitas Harga Saham}

Perusahaan koneksi politik adalah perusahaan yang dengan cara tertentu memiliki ikatan politik atau mencari kedekatan dengan politisi atau pejabat pemerintahan (Purwoto, 2011). Mobarak \& Purbasari (2005) menunjukkan bahwa perusahaan koneksi politik lebih berkemungkinan 6 sampai dengan 22 persen untuk memperoleh lisensi perdagangan dibandingkan dengan para pesaing lainnya dan perusahaan berkoneksi politik sering menciptakan monopoli dalam industri. Pada sampel perusahaan dunia Faccio (2006) menemukan bahwa koneksi politis lebih umum dijumpai di negara yang mempunyai tingkat persepsi korupsi yang lebih tinggi.

Hasil penelitian yang menunjukkan hubungan positif antara koneksi politik dan sinkronisitas harga saham juga didukung oleh Tang et al. (2011) yang disebutkan dalam artikel Lee \& Wang (2017). Penelitian ini menemukan hubungan positif antara koneksi politik dan sinkronisitas harga saham di China. Mereka menjelaskan hubungan politik tersebut mungkin mengarah pada opasitas keuangan karena kegiatan antara perusahaan yang terhubung dan pemerintah sering nonpublik atau tidak dapat diungkapkan.

\subsubsection{Pengaruh Institusional Sinkronisitas Harga Saham \\ Kepemilikan Terhadap}

Investor institusional umumnya dianggap sebagai investor yang terinformasi. Mereka memiliki akses ke sumber daya informasi yang tidak dimiliki investor individu, dan tim mereka termasuk staf penelitian profesional. Keuntungankeuntungan ini dapat membuat penilaian mereka terhadap perusahaan lebih akurat daripada investor individu sehingga dapat meningkatkan kuantitas informasi tingkat perusahaan yang terkandung dalam harga saham. Penelitian tersebut menunjukkan bahwa investor institusional dapat mempengaruhi proses penetapan harga saham dan transaksi mereka berkontribusi dalam menambah informasi spesifik ke dalam harga saham. Hasil penelitian ini menyatakan bahwa terdapat pengaruh signifikan negatif antara investor institusional dan sinkronisitas harga saham (Kun et al., 2018).

Investor institusional secara efektif menjalankan hak kepemilikan mereka untuk memastikan berfungsinya dewan direksi, meningkatkan transparansi, dan keterbukaan informasi ke pasar (Tee, 2017). Investor institusional diharapkan dapat meningkatkan intensitas pemantauan mereka pada perusahaan koneksi politik karena mereka dianggap mengalami masalah agensi dan diperhatikan oleh media, politisi, dan investor publik (Benjamin, Zain, \& Wahab, 2016; Boubakri, Guedhami, Mishra, \& Saffar, 2012).

\subsubsection{Pengaruh ROE Terhadap Sinkronisitas Harga Saham}

Ketika investor ingin berinvestasi, hal utama yang diperhatikan adalah kinerja keuangan. Baik dan buruknya kinerja keuangan suatu perusahaan dapat diukur dengan rasio keuangan salah satunya adalah ROE. Investor akan berinvestasi jika menurutnya akan memperoleh dividen atau keuntungan dan angka laba adalah dasar untuk menentukan dividen. Namun apabila ROE perusahaan tidak menghasilkan nilai bagus atau bahkan minus yang artinya perusahaan mengalami kerugian, maka investor akan menggunakan informasi eksternal dalam pengambilan keputusan (Silviana \& Rocky, 2013).

Berdasarkan hasil penelitian yang dilakukan oleh Haghighat et al. (2015) menemukan hubungan signifikan negatif antara ROE dan sinkronisitas harga saham. Hal ini disebabkan oleh penurunan ROE akan mengakibatkan keraguan investor dan investor akan mencari informasi eksternal. Hasil yang sama didukung oleh Dai, Lu, Yang, \& Zheng (2018); Lee \& Wang (2017); Tangut 
(2017); Watanabe, Imhof, \& Tartaroglu (2019).

\subsubsection{Pengaruh Ukuran Perusahaan Terhadap Sinkronisitas Harga Saham}

Ukuran perusahaan pada umumnya mempengaruhi minat investor dalam berinvestasi. Semakin besar ukuran perusahaan dapat semakin menarik perhatian investor untuk berinvestasi. Perusahaan dengan ukuran besar cenderung memiliki informasi eksternal atau informasi di pasar yang banyak. Oleh karena itu, investor cenderung menggunakan informasi yang beredar di pasar untuk menjadi bahan pertimbangan dalam investasi yang dilakukan (Kim \& Shi, 2012).

Hasil penelitian yang sama dilakukan oleh Santana, Sarquis, Lourenno, Salotti, \& Murcia (2014). Menurut penelitian yang telah dilakukan, ukuran perusahaan berhubungan secara signifikan positif terhadap sinkronisitas harga saham. Perusahaan besar akan lebih menarik perhatian sehingga memiliki informasi diluar perusahaan lebih banyak dan menyebabkan sinkronisitas harga saham meningkat karena investor lebih memilih menggunakan informasi dari luar perusahaan dalam membuat keputusan. Hasil penelitian lainnya yang menunjukkan adanya hubungan signifikan positif antara ukuran perusahaan dan sinkronisitas dilakukan oleh Cheng et al. (2017); Tangut (2017); Wen et al. (2019); Haghighat et al. (2015).

\subsubsection{Pengaruh Leverage Terhadap Sinkronisitas Harga Saham}

Leverage sebagai total utang terhadap total rasio aset untuk tahun fiskal. Leverage tinggi memaparkan perusahaan terhadap risiko keuangan yang lebih besar. Berdasarkan hasil penelitian Gul et al. (2010), dinyatakan terdapat hubungan secara signifikan positif antara leverage dan sinkronisitas harga saham. Hal ini disebabkan oleh keraguan investor dalam pengambilan keputusan ketika perusahaan memiliki leverage yang tinggi sehingga investor membutuhkan informasi dari luar untuk dijadikan pertimbangan pengambilan keputusan. Oleh karena itu, dengan meningkatnya leverage maka sinkronisitas harga saham juga akan meningkat.

Santana et al. (2014) menemukan bahwa leverage memiliki hubungan signifikan positif terhadap sinkronisitas harga saham. Perusahaan bursa efek Sao Paulo, Brasil pada tahun 2005 sampai dengan 2012 merupakan data yang digunakan pada penelitian ini. Hasil penelitian menyatakan perusahaan leverage tinggi akan mengalami sinkronisitas harga saham yang tinggi juga. Hal ini disebabkan para investor mengandalkan informasi dari luar dalam pengambilan keputusan. Hasil penelitian yang sama didukung oleh Rut \& Darmawan (2019); Kan \& Gong, (2017); Kusnadi \& Srinidhi (2018).

\subsubsection{Pengaruh Skewness dan Kurtosis Terhadap Sinkronisitas Harga Saham}

Skew atau skewness merupakan laba mingguan spesifik perusahaan untuk tahun fiskal t. Sedangkan, Kurt atau kurtosis adalahpengembalian mingguan spesifik perusahaan untuk tahun fiskal t. Menurut Hutton, Marcus, \& Tehranian (2009) dan Jin \& Myers (2006) kurtosis dan skewness dari pengembalian mingguan saham digunakan untuk menghitung tingkat sinkronisitas harga saham.

Jin \& Myers (2006) mencatat bahwa skewness yang lebih rendah berarti bahwa ada sejumlah besar outlier negatif dalam distribusi pengembalian, dan mereka menunjukkan kemiringan itu berhubungan negatif dengan sinkronisitas harga saham. Kurtosis yang lebih tinggi dapat diartikan sebagai akibat dari penyimpangan data. Hutton et al. (2009) berpendapat bahwa peristiwa penyimpangan itu akan cenderung melemahkan hubungan antara pengembalian perusahaan dan pengembalian pasar. Hal itu menyebabkan terjadinya hubungan positif antara kurtosis dan sinkronisitas harga saham. 


\subsection{Model Penelitian dan Perumusan Hipotesis}

Model penelitian ini merupakan model penelitian terdahulu yang dilakukan oleh Tee (2017). Model penelitian ini menggunakan variabel sinkronisitas harga saham sebagai variabel dependen. Variabel independen terdiri atas koneksi politik, kepemilikan institusional, ROE, ukuran perusahaan, dan leverage. Selain itu, terdapat variabel kontrol dalam model penelitian ini yaitu skewness dan kurtosis. Model penelitian ini dapat diilustrasikan pada Gambar 2.3 berikut.

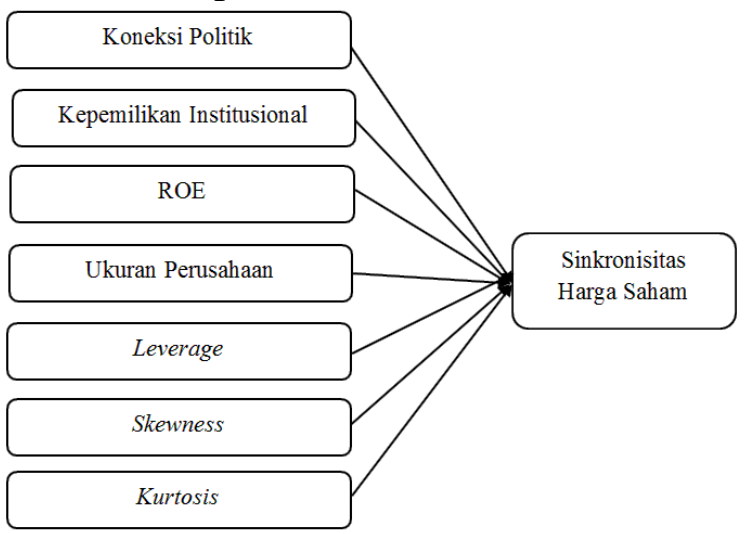

Gambar 2.3 Model Penelitian Pengaruh Koneksi Politik dan Kepemilikan Institusional terhadap Sinkronisitas Harga Saham, sumber: Tee (2017).

Dilihat dari hasil metode penelitian terdahulu yang didukung dengan teori-teori dasar maka dirumuskan hipotesis untuk penelitian ini yaitu sebagai berikut:

$\mathrm{H}_{1}$ : Terdapat hubungan signifikan positif antara perusahaan koneksi politik terhadap sinkronisitas harga saham.

$\mathrm{H}_{2}$ : Terdapat hubungan signifikan negatif antara kepemilikan institusional terhadap sinkronisitas harga saham.

$\mathrm{H}_{3}$ : Terdapat hubungan signifikan negatif antara ROE terhadap sinkronisitas harga saham.

$\mathrm{H}_{4}$ : Terdapat hubungan signifikan positif antara ukuran perusahaan terhadap sinkronisitas harga saham.

$\mathrm{H}_{5}$ : Terdapat hubungan signifikan positif antara Leverage terhadap sinkronisitas harga saham.
$\mathrm{H}_{6}$ : Terdapat hubungan signifikan negatif antara Skewness terhadap sinkronisitas harga saham.

$\mathrm{H}_{7}$ : Terdapat hubungan signifikan positif antara Kurtosis terhadap sinkronisitas harga saham.

\section{METODE PENELITIAN}

\subsection{Rancangan Penelitian}

Data pada penelitian ini menggunakan data sumber sekunder yaitu data laporan keuangan dan laporan tahunan perusahaan LQ45 yang diperoleh dari BEI. Waktu pengumpulan data adalah time series dengan interval waktu tahun 2014 sampai dengan 2018. Untuk variabel kualitatif yaitu variabel koneksi politik menggunakan skala pengukuran data nominal dimana jenis datanya hanya berupa klasifikasi atau pemilihan yang sifatnya hanya membedakan antara satu kelompok dengan kelompok lain tanpa tingkatan tertentu. Sedangkan untuk variabel kuantitatif yaitu variabel sinkronisitas harga saham, kepemilikan institusional, ROE, ukuran perusahaan, leverage, kurtosis, dan skewness menggunakan skala pengukuran data interval yang tidak memiliki nilai nol absolut.

\subsection{Objek Penelitian}

Ciri-ciri objek penelitian ini terdiri atas:

1) Perusahaan indeks LQ45 pada BEI yaitu 45 perusahaan dengan kondisi perusahaan, prospek perusahaan dan nilai transaksi yang tinggi.

2) Laporan perusahaan yang telah diaudit periode tahun 2014 sampai dengan 2018.

3) Laporan tahunan dan laporan keuangan perusahaan memperoleh data yang dibutuhkan dalam mengolah varibael dependen dan independen pada penelitian ini.

\subsection{Definisi Operasional Variabel \\ 3.3.1. Variabel Dependen}

Variabel dependen yang digunakan pada penelitian ini adalah sinkronisitas harga saham. Menurut Kun, B, \& Hu (2018), untuk mengukur sinkronisitas harga saham untuk 
perusahaan $i$ pada tahun fiskal $t$ seperti yang ditunjukkan dalam persamaan berikut ini.

$$
r_{i, w}=a+\beta_{i} x r_{m, w}+\dot{\varepsilon}_{i, w}
$$

Keterangan:

$r_{i, w}=$ return perusahaan $\mathrm{i}$ dalam minggu $\mathrm{w}$

$r_{m, w}=$ return pasar dalam minggu $\mathrm{w}$

Sinkronisitas harga saham kemudian diukur dengan logaritma dari $R^{2}$. Semakin tinggi $R^{2}$ maka informasi perusahaan yang disampaikan pada laporan keuangan tahunan semakin sedikit. Sebaliknya, semakin rendah $R^{2}$ maka informasi perusahaan yang disampaikan pada laporan keuangan tahunan semakin banyak (Gul et al., 2010).

$$
\mathrm{SYNCH}=\log \left(R^{2} /\left(1-R^{2}\right)\right)
$$

\subsubsection{Variabel Independen}

\subsubsection{Koneksi Politik}

Perusahaan dinilai 1 jika didirikan sebagai perusahaan koneksi politik, dan dinilai 0 untuk sebaliknya. Faccio (2006) mengidentifikasi perusahaan dinyatakan berkoneksi politik jika diantara pemegang saham pengendali perusahaan atau pejabat eksekutif adalah anggota parlemen, Perdana Menteri atau menteri kabinet yang berhubungan dengan politik. Mereka juga dapat berhubungan dengan perdana menteri atau menteri kabinet melalui ikatan keluarga atau bisnis. Peneliti mengidentifikasi perusahaan sebagai perusahaan koneksi politik berdasarkan pada informasi yang disediakan dalam laporan tahunan perusahaan untuk setiap tahun.

\subsubsection{Kepemilikan Institusional}

Variabel ini dapat diukur dengan jumlah kepemilikan yang dimiliki institusi atas kepemilikan saham perusahaan tersebut. Kepemilikan institusi dapat berupa institusi lokal maupun institusi asing. Kepemilikan institusional dapat dirumuskan dengan kepemilikan institusional dibagi total saham beredar pada perusahaan tersebut (Kun et al., 2018).

Kepemilikan $=$ Jumlah kepemilikan saham institusi Institusional

\subsubsection{Return On Equity}

ROE digunakan dalam mengukur kemampuan perusahaan menggunakan ekuitas untuk memperoleh laba pada periode tersebut. Semakin rendah ROE akan membuat investor meragukan informasi perusahaan tersebut sehingga investor akan memilih menggunakan informasi pihak eksternal dalam pengambilan keputusan, dan sebaliknya. Dengan demikian samakin rendah ROE maka tingkat sinkronisitas harga saham semakin tinggi. ROE dapat dirumuskan dengan total laba bersih perusahaan dibagi dengan total ekuitas untuk tahun fiskal t (Tee, 2017).

$$
\mathrm{ROE}=\frac{\text { Laba Bersih }}{\text { Total Ekuitas }}
$$

\subsubsection{Ukuran Perusahaan}

Kapitalisasi pasar yang dimiliki sebuah perusahaan dapat menetukan ukuran perusahaan tersebut. Total harga saham yang beredar adalah kapitalisasi pasar perusahaan tersebut. Ukuran perusahaan diperoleh melalui rumus log dari kapitalisasi pasar perusahaan untuk tahun fiskal $t$ (Tee, 2017).

Ukuran perusahaan $=\log$ kapitalisasi pasar

\subsubsection{Leverage}

Leverage adalah total utang perusahaan yang diukur berdasarkan total aset untuk tahun fiskal t (Tee, 2017). Leverage menunjukkan seberapa besar aset perusahaan dibiayai dengan hutang. Semakin tinggi tingkat leverage, investor semakin ragu dengan kemampuan perusahaan dalam melunasinya. Dengan demikian, investor akan menggunakan informasi luar dalam pengambilan keputusan yang menyebabkan semakin tinggi tingkat sinkronisitas harga saham.

$$
\text { Leverage }=\frac{\text { Total Hutang }}{\text { Total Aset }}
$$

\subsubsection{Skewness dan Kurtosis}

Skewness adalah kecenderungan pengembalian mingguan perusahaan-spesifik 
untuk tahun fiskal t. Kurtosis adalah pengembalian mingguan khusus perusahaan untuk tahun fiskal $\mathrm{t}$ (Tee, 2017). Menurut Hutton et al. (2009) kurtosis merupakan kemiringan triwulanan dari pengembalian harian. Kemiringan yang rendah berarti terdapat sejumlah pencilan negatif dalam distribusi pengembalian dan mereka menunjukkan kemiringan itu berhubungan negatif dengan sinkronisitas. Kurtosis yang tinggi diasumsikan sebagai akibat dari terdapat penyimpangan yang jarang terjadi. Peristiwa penyimpangan tersebut akan cenderung melemahkan hubungan antara pengembalian perusahaan dan pengembalian pasar yang akan mengarah ke hubungan positif antara kurtosis dan sinkronisitas harga saham.

\subsection{Teknik Pengumpulan Data}

Data penelitian yang digunakan pada penelitian ini adalah data sekunder yang berasal dari data perusahaan indeks periode 2014 sampai dengan 2018. Data yang diperoleh digunakan untuk menghitung atau mengukur variabel sinkronisitas harga saham, koneksi politik, kepemilikan institusional, ROE, ukuran perusahaan, leverage, skewness, dan kurtosis. Perolehan data didapati dari website https://finance.yahoo.com/ untuk data harga saham mingguan dalam perhitungan variabel sinrkonisitas harga saham sebagai variabel dependen dan www.idx.co.id untuk laporan tahunan dan laporan keuangan tahunan perusahaan LQ45.

\subsection{Metode Analisis Data}

Metode analisis data menggunakan program statistik yaitu perangkat lunak berbasis komputer. Program atau aplikasi statistik yang dimaksud adalah SPSS versi 22 serta aplikasi atau perangkat lunak yang disebut Eviews 10. Melalui SPSS versi 22, uji outlier dan statistik deskriptif dilakukan. Sedangkan aplikasi Eviews 10 digunakan untuk menguji posisi model terbaik melalui Uji Chow diikuti oleh Uji Hausman, koefisien determinasi, uji F, dan uji t.

\subsubsection{Statistik Deskriptif}

Hasil uji statistik deskriptif membantu analisis data dengan menggambarkan, menunjukkan, atau meringkas data variabel penelitian dengan cara yang singkat dan sederhana. Statistik deskriptif tidak memungkinkan mencapai kesimpulan tentang hipotesis yang telah dirumuskan karena statistik deskriptif hanya menampilkan gambaran data variabel yang diproses (Sugiyono, 2013). Statistik deskriptif penting untuk ditampilkan karena dapat mempermudah pembaca atau peneliti mengetahui ringkasan atau kesimpulan atas data-data yang yang diinput serta diolah per variabel mulai dari angka minimun, maksimum, rata-rata dan standar deviasi sehingga dapat menampilkan informasi masing-masing variabel secara sederhana (Indriantoro \& Supomo, 2011).

\subsubsection{Uji Outlier}

Outlier adalah data yang memiliki sifat abnormal dari nilai-nilai lain dalam sampel acak dari suatu populasi. Sebelum pengujian data dimulai, perlu dilakukan uji outlier untukj mengeluarkan data yang bersifat abnormal dalam penelitian supaya penelitian menjadi lebih akurat. Tujuan dilakukannya pengujian outlier ini adalah untuk mengetahui adakah penyimpangan antara data terkumpul dengan rata-rata yang mengakibatkan distribusi data menjadi tidak normal atau (Winarno \& Wahyu, 2015).

\subsubsection{Regresi Data Panel}

Regresi data panel merupakan data yang berkombinasi antara data yang bersifat cross section dan time series. Data panel yang dibentuk menjadi sebuah model dengan regresi disebut dengan model regresi panel. Model regresi panel menampilkan model hubungan variabel dependen dengan variabel independen (Ariefianto, 2012).

\subsection{Pemilihan Model Terbaik \\ 3.5.1. Uji Chow}

Menurut Ariefianto (2012), uji chow adalah tes untuk menentukan model apakah PLS atau FEM paling tepat digunakan dalam 
memperkirakan data panel. Terdapat dua kemungkinan yaitu jika angka prob lebih besar dari 0,05 maka pengujian menggunakan model PLS (Pooled Least Square) adalah yang terbaik pada penelitian ini. Sedangkan, jika angka prob lebih kecil dari 0,05 maka pengujian menggunakan model Fixed Effect Model (FEM) adalah yang terbaik pada penelitian ini dan dilanjutkan dengan uji Hausman.

\subsubsection{Uji Hausman}

Uji Hausman adalah tes statistik untuk memilih model yang akan digunakan antara FEM ataupun REM. Untuk dapat menetukan model yang digunakan, terdapat dua kemungkinan yaitu menggunakan Random Effect Model (REM) jika hasil prob besar dari 0,05 maka sedangkan menggunakan Fixed Effect Model (FEM) jika prob kurang dari 0,05 . Uji hausman dapat dilakukan setelah melakukan uji chow dengan hasil uji chow yang menunjukkan probabilitas kurang dari 0,05 sehingga untuk memilih model terbaik adalah harus dilanjutkan dengan uji chow untuk memastikan apakah FEM atau REM yang terpilih untuk digunakan selanjutnya.

\subsection{Uji Hipotesis}

\subsubsection{Uji F}

Menurut Rahmadani \& Yonesta (2016), uji $\mathrm{F}$ adalah tes atau uji yang mampu mengetahui pengaruh antara variabel bebas terhadap variabel terikat dengan berbarengan. Untuk memenuhi uji $\mathrm{F}$, diperlukan ketentuanketentuan seperti jika pada hasil uji $\mathrm{F}$ angka signifikan menunjukkan angka kurang dari 0,05, maka dikatakan variabel independen berpengaruh secara signifikan terhadap variabel dependen serta model penelitian dikatakan cocok atau sesuai. Dan juga sebaliknya, jika pada hasil uji F menunjukkan angka lebih dari 0,05, maka dikatakan variabel independen tidak berpengaruh secara signifikan terhadap variabel dependen serta model penelitian dikatakan tidak sesuai atau tidak cocok.

\subsubsection{Uji t}

Fungsi uji t antara lain adalah untuk tes lokasi satu sampel dari apakah rata-rata populasi memiliki nilai yang ditentukan dalam hipotesis nol dan uji lokasi dua sampel dari hipotesis nol sedemikian sehingga ratarata dua populasi adalah sama. Berikut ini terdapat syarat untuk menentukan apakah terdapat pengaruh signifikan antar variabel (Rahmadani \& Yonesta, 2016).

\subsubsection{Uji Koefisien Determinasi}

Uji koefisien determinasi atau uji $R$ Square digunakan untuk menunjukkan angka kecocokan atau kesesuaian pada model regresi yang diteliti. Semakin tinggi angka pada hasil uji $R$-square menunjukkan semakin cocoknya model regresi yang dilakukan. Selain itu, uji koefisien determinasi dapat mengetahui kemampuan variabel independen mempengaruhi variabel dependen.

\section{HASIL PENELITIAN}

\subsection{Statistik Deskriptif}

Statistik deskriptif adalah metode penyajian data melalui tabel untuk menganalisis data. Data yang diperoleh disusun, diolah, dan diuji dengan menggunakan dua jenis aplikasi statistika yaitu SPSS versi 22 dan Eviews versi 10. Tabel berikut ini adalah ringkasan penentuan sample yang digunakan selama penelitian dilakukan.

Tabel 1

\section{Pemilihan Sampel dan Data Perusahaan}

\begin{tabular}{|l|r|}
\hline Keterangan & Jumlah \\
\hline $\begin{array}{l}\text { Perusahaan LQ45 yang terdaftar pada } \\
\text { BEI }\end{array}$ & 45 \\
\hline Periode Penelitian Tahun 2014-2018 & 5 \\
\hline Jumlah Data & 225 \\
\hline Data Outlier & 25 \\
\hline Data Obeservasi & $\mathbf{2 0 0}$ \\
\hline
\end{tabular}

Sumber: Data Diolah (2019)

Pengujian statistik deskriptif pada penelitian ini dibantu oleh aplikasi SPSS versi 22. Variabel berdasarkan jenis datanya terdapat variabel kuantitatif dan variabel kualitatif. Variabel kuantitatif adalah variabel yang memiliki angka atau numeric sedangkan variabel kualitatif adalah variabel yang 
mengelompokkan berdasarkan kualitas atau kelompok tertentu tanpa memiliki angka atau numeric pada variabel tersebut. Berikut merupakan hasil uji statistik deskriptif dengan menggunakan aplikasi SPSS versi 22.

Tabel 2

Hasil Uji Statistik Deskriptif Variabel Kuantitatif (Non Dummy)

\begin{tabular}{|l|c|c|c|c|c|}
\hline & N & Min & Max & Mean & Std.dev \\
\hline Sinkronisitas harga Saham & 200 & -6.87 & 1.43 & -1.60 & 1.49 \\
\hline Kepemilikan Institusional & 200 & 0.00 & 0.99 & 0.52 & 0.24 \\
\hline ROE & 200 & -2.64 & 8.91 & 0.22 & 0.69 \\
\hline Ukuran Perusahaan & 200 & 26.84 & 34.09 & 31.17 & 1.42 \\
\hline Leverage & 200 & 0.13 & 1.85 & 0.53 & 0.24 \\
\hline Skewness & 200 & -1.54 & 2.66 & 0.37 & 0.72 \\
\hline Kurtosis & 200 & -0.78 & 12.37 & 1.86 & 2.31 \\
\hline Valid N (listwise) & 200 & & & & \\
\hline
\end{tabular}

Sumber: Data Diolah (2019)

Tabel 3

Hasil Uji Statistik Deskriptif Variabel Kualitatif atau Dummy

\begin{tabular}{|r|l|c|c|}
\hline & \multicolumn{1}{|c|}{ Value } & Frekuensi & Persen \% \\
\hline Koneksi Politik & 1=koneksi politik & 147 & $73,5 \%$ \\
& 0=tidak koneksi politik & 53 & $26,5 \%$ \\
\hline Total & $\mathbf{2 0 0}$ & $\mathbf{1 0 0 \%}$ \\
\hline
\end{tabular}

Sumber : Data Diolah (2019)

\subsection{Hasil Uji Outlier}

Uji outlier bertujuan untuk mengetahui data yang menyimpang pada model penelitian. Sebuah data dikategorikan sebagai outlier ketika data tersebut setelah diuji menunjukkan angka SDR besar dari 1.96 atau kecil dari -1.96. Berdasarkan hasil uji outlier yang dilakukan terhadap variabel penelitian yang terdiri atas sinkronisitas harga saham, koneksi politik, kepemilikan institusional, ROE, leverage, ukuran perusahaan, kurtosis dan skewness menunjukkan terdapatnya 25 data yang angka SDR kecil dari -1.96 seperti yang ditampilkan pada tabel diatas. Oleh karena itu, 25 data tersebut harus dihapus sebelum melakukan pengujian lebih lanjut terhadap model penelitian ini. Data yang dapat digunakan setelah menghapus 25 data outlier ini adalah sejumlah 200 data.

\subsection{Hasil Uji Regresi Panel \\ 4.3.1. Hasil Uji Chow}

Uji Chow dilakukan sebelum melakukan uji hausman yang bertujuan untuk memilih model terbaik antara model PLS dan

FEM.

Tabel 4

Hasil Uji Chow

\begin{tabular}{|l|c|c|c|}
\hline \multicolumn{1}{|c|}{ Effects Test } & Statistic & d.f. & Prob. \\
\hline Cross-section F & 2.142224 & $(44,148)$ & 0.0004 \\
\hline $\begin{array}{l}\text { Cross-section Chi- } \\
\text { square }\end{array}$ & 98.558091 & 44 & 0.0000 \\
\hline
\end{tabular}

Sumber: Data Diolah (2019)

Pada tabel di atas menunjukkan hasil uji Chow yang dilakukan pada penelitian ini. Angka prob pada cross-section Chi-square menunjukkan angka 0,0000 yaitu lebih kecil dari 0,05 dimana menunjukkan bahwa model terbaik yang terpilih pada hasil uji chow berdasarkan ketentuan uji chow adalah model FEM yang dilanjutkan dengan uji Hausman.

\subsubsection{Hasil Uji Hausman}

Pada Tabel 5 menunjukkan hasil uji Hausman yang dilakukan pada penelitian ini. Angka prob pada cross-section random menunjukkan angka 0,0015 yaitu lebih kecil dari 0,05 dimana menunjukkan bahwa model terbaik yang terpilih pada hasil uji hausman berdasarkan ketentuan uji hausman adalah 
model FEM. Dengan demikian, model FEM adalah model terbaik yang terpilih pada penelitian ini dan data dari FEM akan digunakan untuk pengujian berikutnya.

Tabel 5

Hasil Uji Hausman

\begin{tabular}{|c|c|c|c|}
\hline Test Summary & $\begin{array}{c}\text { Chi-Sq. } \\
\text { Statistic }\end{array}$ & $\begin{array}{c}\text { Chi-Sq. } \\
\text { d.f. }\end{array}$ & Prob. \\
\hline $\begin{array}{c}\text { Cross-section } \\
\text { random }\end{array}$ & 23.287871 & 7 & 0.0015 \\
\hline
\end{tabular}

Sumber: Data Diolah (2019)

\subsection{Hasil Uji Hipotesis}

\subsubsection{Hasil Uji F}

Pengujian ini bertujuan untuk mengetahui adakah pengaruh yang signifikan pada model penelitian ini atau dengan kata lain apakah model yang dipilih pada penelitian ini cocok atau sesuai. Angka pada tabel 4.6 hasil uji F ini diambil dari data FEM sebagaimana merupakan model terbaik yang terpilih untuk digunakan pada penelitian ini. Angka prob ( $F$ Statistic) ini menunjukkan angka 0,000000 yaitu lebih kecil dari 0,05 dimana menunjukkan bahwa model penelitian ini cocok atau sesuai atau variabel independen berpengaruh signifikan secara simultan terhadap variabel dependen.

Tabel 6

Hasil Uji F

\begin{tabular}{|l|l|}
\hline Variabel Dependen & Prob (F Statistic) \\
\hline Sinkronisitas Harga Saham & 0,000000 \\
\hline
\end{tabular}

Sumber: Data Diolah (2019)

\subsubsection{Hasil Uji t}

Pengujian ini bertujuan untuk membuktikan apakah terdapat pengaruh yang signifikan antara variabel independen dan control terhadap variabel dependen. Dari hasil Uji t seperti pada tabel 4.7 yakni koneksi politik kepemilikan institusional, ROE, ukuran perusahaan, leverage, skewness, dan kurtosis sebagai variabel independen. Variabel kepemilikan institusional, ukuran perusahaan dan Kurtosis menunjukkan pengaruh signifikan terhadap sinkronisitas harga saham sedangkan variabel koneksi politik, ROE, leverage, dan skew menunjukkan hasil tidak signifikan berpengaruh terhadap sinkronisitas harga saham sebagai variabel dependen.

Tabel 7

Hasil Uji $t$

\begin{tabular}{|l|c|c|c|c|}
\hline \multicolumn{1}{|c|}{ Variabel } & Koefisien & Statistis-t & Prob. & Kesimpulan \\
\hline \multicolumn{1}{|c|}{$\mathrm{C}$} & -17.2155 & 4.0307 & 0.0000 & \\
\hline Koneksi Politik & -0.4542 & -0.7916 & 0.4299 & Tidak Signifikan \\
\hline Kepemilikan Institusional & -2.4669 & -3.2399 & 0.0015 & Signifikan Negatif \\
\hline ROE & -0.1722 & -1.2208 & 0.2241 & Tidak Signifikan \\
\hline Ukuran Perusahaan & 0.5500 & 0.1254 & 0.0000 & Signifikan Positif \\
\hline Leverage & -0.0718 & -0.0775 & 0.9383 & Tidak Signifikan \\
\hline Skewness & -0.0791 & -0.5666 & 0.5718 & Tidak Signifikan \\
\hline Kurtosis & 0.1052 & 2.1598 & 0.0324 & Signifikan Positif \\
\hline
\end{tabular}

Sumber: Data Diolah (2019)

Persamaan regresi untuk model penelitian pada karya ilmiah ini dapat dirumuskan sebagai berikut.

SYNCH $=-17.21558-0.454250 \mathrm{POLCON}-$ 2.466953INSOW $-0.172263 \mathrm{ROE}+0.550095 \mathrm{SIZE}-$ 0.071870 LEV -0.079176SKEW + 0.105210KURT

Keterangan:

POLCON $=$ Koneksi politik

INSOW = Kepemilikan institusional

ROE = Return On Equity

SIZE $\quad=$ Ukuran Perusahaan

LEV = Leverage

\section{SKEW = Skewness \\ KURT $=$ Kurtosis}

\section{H1: Perusahaan koneksi politik berpengaruh signifikan positif terhadap sinkronisitas harga saham.}

Hipotesis $\mathrm{H}_{1}$ ini ditolak karena dari berdasarkan hasil pengujian yang telah dilakukan tidak ditemukan adanya hubungan yang signifikan antara hubungan koneksi politik dan sinkronisitas harga saham pada perusahaan LQ45 yang terdaftar di BEI 
Indonesia. Hal ini mengungkapkan bahwa perusahaan yang berkoneksi politik tidak selalu menghambat dan membatasi informasi spesifik perusahaan pada harga saham. Hasil ini sependapat dengan Kusnadi \& Srinidhi (2018) dan Lee \& Wang (2017) yang telah melakukan penelitian dengan variabel sama.

\section{H2: Kepemilikan institusional berpengaruh signifikan negatif terhadap sinkronisitas harga saham.}

Hasil penelitian ini menunjukkan bahwa kepemilikan institusional pada perusahaan LQ45 yang terdaftar di BEI Indonesia sangat mempengaruhi sinkronisitas harga saham. Investor institusional secara efektif menjalankan hak kepemilikan mereka dan pengalaman untuk memastikan transparansi dan keterbukaan informasi perusahaan ke pasar. Sehingga semakin besar kepemilikan institusional dapat menyebabkan sinkronisitas harga saham yang semakin rendah dan juga sebaliknya. Hasil ini sependapat dengan Haghighat et al.(2015); Lyimo \& Jain (2014); Dai, Lu, Yang, \& Zheng (2018) yang telah melakukan penelitian terhadap variabel sama.

\section{H3: ROE berpengaruh signifikan negatif terhadap sinkronisitas harga saham.}

Penelitian ini tidak menemukan pengaruh yang signifikan antara variabel ROE dan sinkronisitas harga saham. Dengan demikian, dapat dikatakan bahwa perusahaan dengan ROE tinggi ataupun rendah tidak mempengaruhi keterbukaan informasi perusahaan ke pasar. Hasil penelitian yang sama dilakukan oleh Rut \& Darmawan (2019); Sasongko \& Wulandari (2006); Wen, Yuan, \& Zhou (2019).

\section{H4: Ukuran perusahaan berpengaruh signifikan positif terhadap sinkronisitas harga saham.}

Penelitian ini menunjukkan hasil adanya pengaruh signifikan variabel ukuran perusahaan terhadap variabel sinkronisitas harga saham. Hal ini menunjukkan bahwa semakin besar ukuran perusahaan maka semakin tinggi tingkat sinkronisitas harga saham karena semakin banyaknya informasi yang beredar menjadi pertimbangan investor dalam mengambil keputusan berinvestasi. Ukuran perusahaan yang semakin besar juga dapat menyebabkan kesulitan dalam memastikan semua informasi yang disediakan seluruhnya tercermin pada laporan keuangan. Hasil penelitian berpendapat sama dengan (Cheng et al., 2017; Kim \& Shi, 2012; Santana et al., 2014; Tangut, 2017; Wen et al., 2019).

\section{H5: Leverage berpengaruh signifikan positif terhadap sinkronisitas harga saham. \\ Penelitian ini menunjukkan hasil tidak} adanya pengaruh secara signifikan antara variabel leverage dan variabel sinkronisitas harga saham. Hal ini dapat diasumsikan bahwa tinggi atau rendahnya leverage perusahaan tidak berhubungan dengan tingkat keterbukaan informasi perusahaan di pasar sehingga tidak mempengaruhi sinkronisitas harga saham. Hasil penelitian ini bertolak belakang dengan penelitian Gul et al., (2010) dan berpendapat sama dengan penelitian Liu ( 2015); Wen et al. (2019).

\section{H6: Skewness berpengaruh signifikan negatif terhadap sinkronisitas harga saham.}

Penelitian ini menunjukkan hasil tidak terdapat hubungan signifikan antara variabel skewness dan variabel sinkronisitas harga saham. Variabel Skewness pada hasil uji t kolom prob menunjukkan angka 0.5718 atau lebih besar dari 0,05 dan kolom koefisien menunjukkan angka -0.079176. Angka tersebut mencerminkan bahwa variabel Skewness tidak berhubungan signifikan terhadap variabel sinkronisitas harga saham. Hasil ini berbeda dengan penelitian yang dilakukan oleh Watanabe, Imhof, \& Tartaroglu (2019).

\section{H7: Kurtosis berpengaruh signifikan positif terhadap sinkronisitas harga saham.}

Penelitian ini menunjukkan hasil adanya pengaruh signifikan variabel kurtosis terhadap variabel sinkronisitas harga saham. 
Variabel kurtosis pada hasil uji t kolom prob menunjukkan angka 0.0324 atau lebih kecil dari 0,05 dan kolom koefisien menunjukkan angka 0.105210. Angka tersebut mencerminkan bahwa variabel Kurtosis berpengaruh signifikan positif terhadap variabel sinkronisitas harga saham. Hasil penelitian ini didukung oleh pendapat sama dari penelitian yang dilakukan oleh Amaya \& Jacobs (2015); Haghighat et al. (2015).

\subsubsection{Hasil Uji Koefisien Determinasi}

Koefisien determinasi dilakukan untuk mengetahui tingkat kesesuaian model penelitian yang dipilih. Berdasarkan hasil uji, angka adjusted $R$ squared menunjukkan angka 0,588202 yang berarti variabel independen pada model dapat menjelaskan variabel dependen sebesar $58,82 \%$.

Tabel 8

Hasil Uji Koefisien Determinasi

\begin{tabular}{|c|c|}
\hline Adjusted $R$-squared & 0.588202 \\
\hline
\end{tabular}

Sumber : Data Diolah (2019)

\section{KESIMPULAN}

\subsection{Kesimpulan}

Penelitian ini dilakukan untuk mengetahui pengaruh variabel independen berupa variabel koneksi politik, kepemilikan institusional, ROE, ukuran perusahaan, dan leverage terhadap variabel dependen, yaitu sinkronisitas harga saham dan dilengkapi dengan variabel kontrol yang Skewness, dan Kurtosis. Sample pada penelitian ini berupa indeks LQ45 yang terdapat 45 perusahaan pada periode 2014 hingga 2018. Penelitian dilakukan dengan bantuan aplikasi Eviews versi 10 dan SPSS versi 22.

Penelitian dari karya ilmiah ini menghasilkan bahwa variabel koneksi politik tidak berhubungan signifikan terhadap sinkronisitas harga saham dimana hipotesis penelitian ini adalah bahwa variabel koneksi politik dan kurtosis memiliki hubungan positif signifikan terhadap variabel sinkronisitas harga saham. Variabel kepemilikan institusional menunjukkan hasil signifikan negatif terhadap variabel sinkronisitas harga saham dan variabel ukuran perusahaan menunjukkan hasil signifikan positif berpengaruh terhadap variabel sinkronisitas harga saham. sedangkan variabel lainnya yaitu ROE, leverage, dan skewness tidak menunjukkan adanya hubungan signifikan terhadap sinkronisitas harga saham.

\subsection{Keterbatasan}

Keterbatasan pada saat melakukan penelitian ini dapat diuraikan dibawah ini.

1. Terbatasnya informasi pada beberapa laporan tahunan perusahaan yang menyebabkan sulitnya mendapatkan informasi yang diinginkan seperti untuk mengetahui kepemilikan institusional dimana pada beberapa laporan tahunan perusahaan hanya menampilkan kepemilikan asing dan lokal sehingga tidak dapat mengetahui pada kepemilikan asing dan lokal masing-masing terdapat berapa persen kepemilikan institusional.

2. Sample penelitian ini hanya berfokus pada perusahaan LQ45 pada BEI sehingga jika menggunakan sample lain mungkin akan terdapat perbedaan pada hasil penelitian.

\subsection{Rekomendasi}

Rekomendasi atau saran yang diberikan dari penulis selama dilakukannya penelitian ini antara lain:

1. Melakukan perbandingan penelitian pada perusahaan bursa efek negara maju dan bursa efek negara berkembang karena pada pasar modal negara maju dan negara berkembang terdapat unsur yang berbeda sehingga kemungkinan memperoleh hasil uji yang berbeda.

2. Menambahkan variabel lain seperti kualitas audit, kepemilikan keluarga, dan lain-lain pada penelitian selanjutnya.

\section{DAFTAR PUSTAKA}

Amaya, D., \& Jacobs, K. (2015). Does realized skewness predict the crosssection.

Ariefianto, M. D. (2012). Ekonometrika esensi dan aplikasi dengan menggunakan 
EViews, 11(1).

Benjamin, S. J., Zain, M. M., \& Wahab, E. A. A. (2016). Political Connections and Dividend Payouts in Malaysia: the Influence of Institutional Investors.

Boubakri, N., Guedhami, O., Mishra, D., \& Saffar, W. (2012). Political connections and the cost of equity capital (254 cit). Journal of Corporate Finance, 18(3), 541-559.

https://doi.org/10.1016/j.jcorpfin.2012.0 2.005

Cheng, H., Lim, K. G., Sing, T. F., \& Wang, L. (2017). Industry integration and stock price synchronicity.

Claessens, S., Feijen, E., \& Laeven, L. (2008). Political connections and preferential access to finance: The role of campaign contributions. Journal of Financial Economics, 88(3), 554-580. https://doi.org/10.1016/j.jfineco.2006.11 .003

Dai, J., Lu, C., Yang, Y., \& Zheng, Y. (2018). Is the social responsibility information disclosed by the companies really valuable?-Evidence from Chinese stock price synchronicity. Sustainability, 10(10), https://doi.org/10.3390/su10103578

Du, J., Hao, H., \& Xu, C. (2007). What Determines the Synchronicity of Stock Price Movements in the Shanghai and Shenzhen Stock Exchanges. ShanghaiHong Kong Development Institute Occasional Paper Series (2001-2007), (August).

Faccio, M. (2006). Politically Connected Firm, 96(1), 369-386.

Faccio, M., Masulis, R. W., \& Mcconnell, J. J. (2006). American Finance Association Political Connections and Corporate Bailouts. The Journal of Finance, 61(6), 2597-2635.

https://doi.org/10.1111/j.15406261.2006.01000.x

Farooq, O., Ahmed, N., \& Bouaddi, M. (2018). Stock price synchronicity and its effect on stock market volatility: evidence from the MENA region. American $J$. Finance and Accounting, 5(3), 276-292.
Fernandes, N., \& Ferreira, M. A. (2009). Insider trading laws and stock price informativeness. Review of Financial Studies, 22(5), 1845-1887. https://doi.org/10.1093/rfs/hhn066

Gul, F. A., Kim, J. B., \& Qiu, A. A. (2010). Ownership concentration, foreign shareholding, audit quality, and stock price synchronicity: Evidence from China. Journal of Financial Economics, 95(3), 425-442. https://doi.org/10.1016/j.jfineco.2009.11.005

Haghighat, A., Farhangzadeh, B., \& Haghighat, M. (2015). The Impact of Institutional Ownership on Stock Price Synchronicity and Crash. International Journal of Business and Social Science, 6(4), 181-189.

Hutton, A. P., Marcus, A. J., \& Tehranian, H. (2009). Opaque financial reports, R2, and crash risk. Journal of Financial Economics, 94(1), 67-86. https://doi.org/10.1016/j.jfineco.2008.10.003

Indriantoro, N., \& Supomo, B. (2011). Metodologi Penelitian Bisnis Untuk Akuntansi Dan Manajemen, 4(1), 20082009.

Jin, L., \& Myers, S. C. (2006). R2around the world: New theory and new tests. Journal of Financial Economics, 79(2), 257-292. https://doi.org/10.1016/j.jfineco.2004.11.003

Kan, S., \& Gong, S. (2017). Does high stock return synchronicity indicate high or low price informativeness? evidence from a regulatory experiment. Interna-tional Review of Finance, 18(1), 59-90. https://doi.org/10.1111/ir

Kim, J. B., \& Shi, H. (2012). IFRS reporting, firm-specific information flows, and institutional environments: International evidence. Review of Accounting Studies, 17(3), 474-517. https://doi.org/10.1007/s11142-012-9190-y

Kun, L., B, L. Y., \& Hu, X. (2018). The Impact of Institutional Investors on Stock Price Synchronicity: Evidence from the Shanghai Stock Market. https://doi.org/10.1007/978-3-319-59280-0 
Kusnadi, Y., \& Srinidhi, B. (2018). CrossCountry Differences in the Effect of Political Connections on Stock Price Informativeness. Ssrn. https://doi.org$/ 10.2139 /$ ssrn.3109232

Lee, W., \& Wang, L. (2017). Do political connections affect stock price crash risk? Firm-level evidence from China. Review of Quantitative Finance and Accounting, 48(3), 643-676. https://doi.org/10.1007/s11156-016-0563-3

Liu, B., \& Zhang, X. (2018). Investor Financial Literacy and Stock Price Synchronicity: A Cross-Country Study. Review of Contemporary Business Research, 6(1), 26-37. https://doi.org/10.15640/rcbr.v6n2a4

Liu, Z. (2015). Institutional investors ' effects on Stock Price Synchronicities: Evidence of Shanghai Stock Exchange Statement of co-authorship, (June), 1-49. Lyimo, G. D. (2014). Smoothness, Earnings Surprise and Stock Price Informativeness . Evidence from Indian Stock Market, 4(2), 385-394. https://doi.org/10.6007/IJARAFMS/v4-i2/936

Lyimo, G. D., \& Jain, G. (2014). Accrual Quality and Stock Price Informativeness : Evidence from India ., 5(12), 88-96.

Mobarak, A. mushfiq, \& Purbasari, D. (2005). $\mathrm{P}$ Olitical $\mathrm{T}$ Rade $\mathrm{P}$ Rotection in $\mathrm{D}$ Eveloping C Ountries :, 2004, 0-47.

Morck, R., Yeung, B., Yu, W., Deardorff, A., Fox, M., Froot, K., ... Yu, W. (2000). The Information Content of Stock Markets: Why Do Emerging Markets Have Synchronous Stock Price Movements? The Information Content of Stock Markets: Why Do Emerging Markets Have Synchronous Stock Price Movements?

Piotroski, J. D., \& Roulstone, B. T. (2016). The Influence of Analysts , Institutional Investors , and Insiders on the Incorporation of Market , Industry, and Firm-Specific Information into Stock Prices Author ( s ): Joseph D . Piotroski and Barren T . Roulstone Source: The Accounting Review , Vol, 79(4), 1119
1151.

Piotroski, J. D., Wong, T. J., \& Zhang, T. (2015). Political incentives to suppress negative information: Evidence from Chinese listed firms. Journal of Accounting Research, 53(2), 405-459. https://doi.org/10.1111/1475679X.12071

Purwoto, L. (2011). Pengaruh koneksi politis, kepemilikan pemerintah dan keburaman laporan keuangan terhadap kesinkronan dan risiko crash harga saham.

Rahmadani, \& Yonesta, E. (2016). Analisis Regresi Data Panel Pada Pemodelan Produksi Panen Kelapa Sawit di Kebun Sawit Plasma Kampung Buatan Baru, (2016).

Rut, U. M., \& Darmawan, A. (2019). Effect of DER , ROA , ROE , EPS and MVA on Stock Prices in Sharia Indonesian Stock Index. Journal Of Applaied Accounting and Taxation, 4(1), 15-22.

Santana, V. de Ff., Sarquis, R. W., Lourenno, I., Salotti, B. M., \& Murcia, F. D.-R. (2014). Economic Effects of IFRS Adoption in Brazil: An Empirical Analysis of Stock Price Synchronicity. SSRN Electronic Journal. https://doi.org/10.2139/ssrn.2383363

Sasongko, N., \& Wulandari, N. (2006). Pengaruh EVA dan Rasio-rasio Profitabilitas Terhadap Harga Saham. Jurnal Akuntansi Dan Keuangan, 19(1), 64-80. Retrieved from http://webkuliah.unimedia.ac.id/

Silviana, \& Rocky. (2013). Analysis of return on assets and earnings per share on the stock market in the banking companies in Bursa Efek Indonesia (Indonesia Stock Exchange). Journal of Global Business \& Economics, 7(1), 119-125. Retrieved from http://search.ebscohost.com/login.aspx?direct=true \& $\mathrm{db}=\mathrm{bth} \& \mathrm{AN}=90566998 \&$ site $=$ edslive\&authtype $=$ uid

Sugiyono. (2013). Metode Penelitian Pendidikan Pendekatan Kuantitatif, Kualitatif, dan R\&D, 2006-2007.

Tangut, J. C. (2017). Effects of Financial Leverage on Stock Returns of Non- 
Financial Companies Listed in the Nairobi Securities Exchange. International Journal of Economics and Business Research, 4(1), 7-11.

Tee, C. M. (2017). Political connections , institutional investors monitoring and stock price synchronicity Evidence from Malaysian firms. https://doi.org/10.1108/MF-03-2017-0099

Watanabe, O. V, Imhof, M. J., \& Tartaroglu, S. (2019). Transparency Regulation and Stock Price Informativeness: Evidence from the European Union's Transparency Directive. Journal of International Accounting Research. https://doi.org/10.2308/jiar-52383

Wen, F., Yuan, Y., \& Zhou, W.-X. (2019). Cross-shareholding networks and stock price synchronicity: Evidence from China. Retrieved from http://arxiv.org/abs/1903.01655

Winarno, \& Wahyu, W. (2015). Analisis Ekonometrika dan Statistik dengan Eviews, 2014-2016. 